\title{
Critical appraisal and pooled analysis of telmisartan alone or in combination with hydrochlorothiazide for achieving blood pressure goals
}

This article was published in the following Dove Press journal:

Integrated Blood Pressure Control

2 June 2010

Number of times this article has been viewed

\section{Satoshi Morimoto \\ Nobuyuki Takahashi \\ Tatsuyori Morita \\ Kazunori Someya \\ Nagaoki Toyoda \\ Toshiji Iwasaka}

Second Department of Internal Medicine, Kansai Medical University

2-3-I, Shinmachi, Hirakata,

Osaka 573-II9I, Japan
Correspondence: Satoshi Morimoto 2-3-I, Shinmachi, Hirakata,

Osaka 573-1191, Japan

Tel +81728040101

Fax +8I 728042865

Email morimots@hirakata.kmu.ac.jp

\begin{abstract}
Rigid control of blood pressure (BP) is essential to prevent cardiovascular disease. However, only about $40 \%$ of hypertensive patients undergoing pharmacological intervention with a single agent achieve their BP goals in contemporary clinical practice. Combined therapy using currently available agents is effective in maximizing treatment outcome, although it raises medical costs and decreases the drug compliance rate. To overcome such negative consequences, a combination tablet containing an angiotensin II receptor blocker (ARB) with a small dose of hydrochlorothiazide (HCTZ) is now available on the international market, including Japan. This article briefly describes the unique properties of telmisartan, a highly selective ARB for the angiotensin II type 1 receptor, including its long-acting characteristics and recent prospective multicenter randomized clinical trials, followed by a description of a newly-introduced combination tablet in Japan, which contains telmisartan and HCTZ. This article also reviews its safety and efficacy based on currently available evidence. Finally, evidence comparing telmisartan/HCTZ with other combination therapies is presented.
\end{abstract}

Keywords: angiotensin II receptor blocker, ARB, blood pressure, hypertension, diuretics, PPAR- $\gamma$

\section{Introduction}

The Japanese Society of Hypertension's Guidelines for the Management of Hypertension 2009 (JSH 2009) ${ }^{1}$ recommends rigid control of blood pressure (BP) and a target BP level based on a patient's clinical condition in order to prevent the onset of vascular diseases including stroke and myocardial infarction (MI). However, only $40 \%$ of patients with hypertension achieve the target BP goal in contemporary clinical practice, indicating the difficulty of BP management with a single hypertensive drug. ${ }^{2}$ Therefore, the revised version of JSH 2009 recommends the use of more than one antihypertensive drug with a different mechanism of action for patients who fail to achieve BP goals with a single agent. Among possible antihypertensive agents, the combination of angiotensin II receptor blocker (ARB) with a small dose of diuretic not only offers synergistic antihypertensive effects but also provides possible benefits other than BP control.

Diuretic agents achieve antihypertensive effects by promoting renal $\mathrm{Na}^{+}$excretion and simultaneously activate the renin-angiotensin system. On the other hand, ARBs inhibit 
the activated renin-angiotensin system, possibly promoting the synergistic antihypertensive effect with the concomitant use of an ARB and diuretic agent. Adverse effects on metabolic pathways, such as hypokalemia, decreased carbohydrate tolerance, and hyperuricemia, are a common concern with the use of diuretic agents. In contrast, ARBs are known to elevate serum $\mathrm{K}^{+}$levels and improve insulin sensitivity, thereby possibly balancing out the adverse effects of a diuretic agent on the metabolic pathway. A small dose of the diuretic agent also is considered to be minimized by elevation of uric acid level.

In addition, considering salt-sensitive hypertension is essential for hypertension management, a condition that is common in Japanese. Administration of ARBs is generally recommended for patients with organ damage. The renin-angiotensin system is accelerated with decreasing intake of salt, but inhibited when salt intake is increased. Hence, limiting the intake of salt should be recommended when ARBs are administered for patients with salt-sensitive hypertension, although the concomitant use of a diuretic agent is expected to have the same effect as limiting the intake of salt by promoting $\mathrm{Na}^{+}$excretion and possibly enhancing the anti-hypertensive effect of ARBs. ${ }^{3}$

\section{Properties of telmisartan}

Angiotensin II type 1 (AT1) receptor blockers, which act by selectively blocking the binding of angiotensin II to the AT1 receptor, are widely used in current antihypertensive therapy. ${ }^{4-6}$ ARBs are reported to have benefits other than BP management and have demonstrated cardiovascular, cerebral, and renal protective effects by inhibiting renin-angiotensin activation at tissue levels. ${ }^{7-9}$

Telmisartan is an ARB that is highly selective for the AT1 receptor and has a long duration of action due to its long terminal elimination half-life. ${ }^{10,11}$ Its longer half- life was demonstrated in the MICADO study (Table 1), ${ }^{12}$ which evaluated two identically designed multinational, randomized, double-blind, forced-titration studies. A total of 930 patients were enrolled in this study. Patients were divided either into the telmisartan group (40-80 mg/day) or into the valsartan group (80-160 mg/day) and followed up for 8 weeks. Uptitration occurred after 2 weeks of low-dose treatment. Following 4 weeks of high-dose therapy, patients underwent either a 1-day double-blind active treatment or placebo treatment. After an additional 2-week active treatment, a crossover was conducted. The result was very impressive in that the last 6-hour mean diastolic BP was decreased by $7.6 \pm 7.9 \mathrm{mmHg}$ in the telmisartan group $(\mathrm{n}=447)$ compared with $5.8 \pm 7.8 \mathrm{mmHg}$ in the valsartan group $(P=0.0044)$ after active therapy. Similarly, the telmisartan group showed reduction in the last 6-hour mean systolic BP of $11.1 \mathrm{mmHg}$, whereas it was only $9.1 \mathrm{mmHg}$ in the valsartan group ( $P=0.0066)$. After the placebo therapy, the telmisartan group $(n=437)$ showed a reduction in 24-hour mean diastolic $\mathrm{BP}$ of $7.2 \pm 6.5 \mathrm{mmHg}$ compared with $5.5 \pm 6.2 \mathrm{mmHg}$ in the valsartan group $(\mathrm{n}=431)(P=0.0004)$. Following the placebo therapy, reduction in 24-hour mean systolic BP was $10.7 \mathrm{mmHg}$ in the telmisartan group and $8.7 \mathrm{mmHg}$ in the valsartan group $(P=0.0024)$. The mean reductions in diastolic and systolic BP were significantly higher in the telmisartan group than in the valsartan group. Therefore, it was concluded that telmisartan offers more sustained BP control because of its long half-life.

Telmisartan is also known to exhibit peroxisome proliferator-activated receptor gamma (PPAR- $\gamma$ ) activation, and thereby yields a favorable influence on glucose and lipid metabolism by improving insulin resistance. ${ }^{13}$ Amongst available ARBs in addition to telmisartan, candesartan, irbesartan, and losartan were reported to

Table I Summary of clinical trials investigating efficacy of telmisartan

\begin{tabular}{lll}
\hline $\begin{array}{l}\text { Names of the clinical trials } \\
\text { or the authors }\end{array}$ & Study subjects & Main results \\
\hline $\begin{array}{l}\text { MICADO study }{ }^{12} \\
\text { Miura et al }{ }^{20}\end{array}$ & $\begin{array}{l}\text { Hypertensive patients } \\
\text { Hypertensive patients } \\
\text { with type 2 diabetes }\end{array}$ & $\begin{array}{l}\text { Greater sustained BP reduction than valsartan } \\
\text { Greater improvement of insulin resistance, } \\
\text { elevation of adiponectin, and reduction } \\
\text { in CRP than valsartan or candesartan }\end{array}$ \\
ONTARGET study ${ }^{27}$ & Patients at high-risk & $\begin{array}{l}\text { Equivalent efficacy in preventing } \\
\text { cardiovascular events as ramipril }\end{array}$ \\
TRANSCEND study ${ }^{28}$ & $\begin{array}{l}\text { Patients at high-risk who are } \\
\text { intolerant to ACE inhibitors }\end{array}$ & $\begin{array}{l}\text { Equivalent efficacy in preventing cardiovascular } \\
\text { events as placebo }\end{array}$ \\
& & $\begin{array}{l}\text { Tolerance of telmisartan } \\
\text { in patients intolerant to ACE inhibitors }\end{array}$ \\
\hline
\end{tabular}

Abbreviations: $\mathrm{BP}$, blood pressure; $\mathrm{CRP}, \mathrm{C}$-reactive protein; $\mathrm{ACE}$, angiotensin-converting enzyme. 
activate PPAR $-\gamma \cdot{ }^{14-16}$ However, telmisartan has the strongest ability to activate PPAR- $\gamma$ in vitro compared with other ARBs. ${ }^{13}$ PPAR $-\gamma$ is an established therapeutic target in the treatment of insulin resistance, diabetes, and the metabolic syndrome. ${ }^{17,18}$ Telmisartan was also demonstrated to have a selective PPAR- $\gamma$ activation effect and to ameliorate insulin resistance. ${ }^{19}$ In fact, replacement of valsartan and candesartan by telmisartan in hypertensive patients with type 2 diabetes demonstrated improvement of insulin resistance, elevation of adiponectin, and reduction in high-sensitive C-reactive protein (hs-CRP). ${ }^{20}$ This study, conducted by Miura et al included 18 hypertensive type 2 diabetes patients aged 36-79 years. These patients were treated with valsartan $(80 \mathrm{mg} /$ day, $\mathrm{n}=11)$ or candesartan ( $8 \mathrm{mg} /$ day, $\mathrm{n}=7$ ) for more than 6 months. During the therapeutic period, clinical and biochemical changes were not observed in these patients. The patients then received treatment with telmisartan $(40 \mathrm{mg} /$ day $)$, instead of the previous ARBs, for 12 weeks. Fasting insulin levels were significantly decreased after telmisartan treatment $(10.7 \pm 3.8$ to $8.6 \pm 2.7 \mathrm{mU} / \mathrm{L}, P<0.01)$, although reduction in fasting plasma glucose levels (132.5 \pm 55.1 to $126.5 \pm 39.3 \mathrm{mg} / \mathrm{dL}$ ) and glycosylated hemoglobin $\left(\mathrm{HbA}_{1 \mathrm{c}}\right)$ showed no significant difference $(6.89 \pm 0.89$ to $6.79 \pm 0.96)$. Significant elevation in serum adiponectin levels $(6.95 \pm 2.91$ to $7.97 \pm 3.48 \mu \mathrm{g} / \mathrm{mL}, P<0.005)$ and a significant reduction in hs-CRP levels $(0.154 \pm 0.155$ to $0.109 \pm 0.120 \mathrm{mg} / \mathrm{dL}, P<0.05)$ were observed in these patients. Adiponectin and hs-CRP are closely associated with insulin resistance and development of atherosclerosis. ${ }^{21,22}$ Thus, this study suggested that telmisartan has beneficial effects on the risk factors for cardiovascular disease, which is a major concern in the treatment of type 2 diabetes. Therefore, it is reasonable to select telmisartan for hypertensive patients with metabolic syndrome or insulin resistance (Figure 1).

\section{ONTARGET and TRANSCEND trials}

Angiotensin-converting enzyme (ACE) inhibitors were the former standard renin-angiotensin system blockers, proven to have benefits other than BP control. Previous randomized controlled trials enrolling approximately 150,000 patients demonstrated that ACE inhibitors decreased incidences of death, myocardial infarction, stroke, and heart failure among patients with heart failure. ${ }^{23}$ They also showed the reduction of unfavorable events including left ventricular dysfunction, previous vascular disease, and high-risk diabetes. ${ }^{24,25}$ Although ACE inhibitors and ARBs have been classified as renin-angiotensin system blockers, ARBs have not shown their effectiveness on myocardial infarction. Furthermore, data from 26 large-scale trials comparing an ACE inhibitor against $A R B$ with placebo or another drug class demonstrated that ACE inhibitors, but not ARBs, show evidence of blood pressure-independent effects on the risk of major coronary disease events. ${ }^{26}$ To evaluate the role of ARBs as an alternative or an addition to ACE inhibitors for preventing cardiovascular events, a group of investigators evaluated whether the ARB telmisartan was inferior to the ACE inhibitor ramipril in a study called Ongoing Telmisartan Alone and in Combination with Ramipril Global Endpoint Trial (ONTARGET). They also investigated whether a combination of the two drugs was superior to ramipril alone as a treatment to prevent cardiovascular events in high-risk patients who suffered from cardiovascular disease or diabetes mellitus but did not have heart failure. ${ }^{27}$ At a median follow-up of 56 months, the primary composite outcomes, including death from cardiovascular diseases, myocardial infarction, stroke, or

\section{Telmisartan}

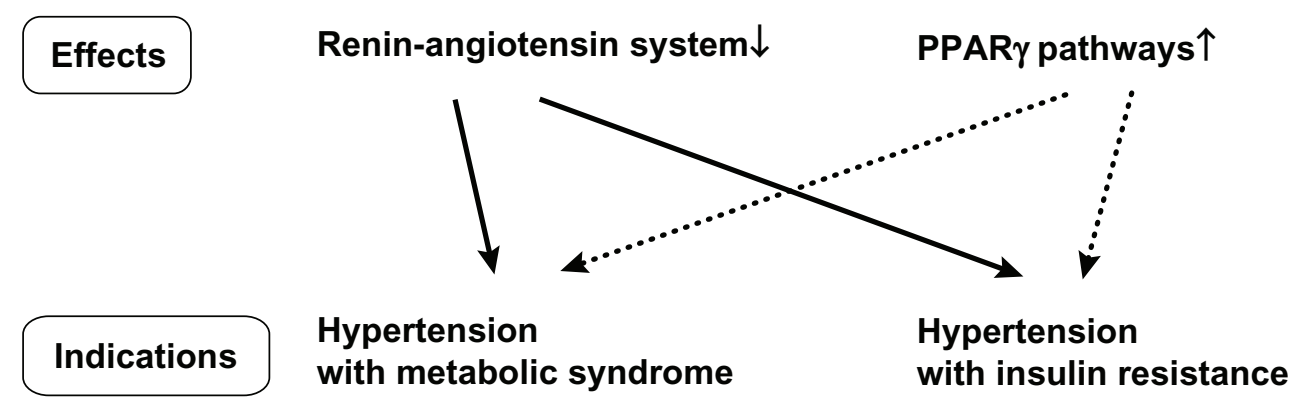

Figure I Ideal indication of telmisartan.

Abbreviation: PPAR $\gamma$, peroxisome proliferator activated receptor gamma. 
hospitalization for heart failure, was similar in the ramipril $(16.5 \%)$ and telmisartan groups (16.7\%). As expected, the ramipril group had higher rates of cough $(4.2 \%$ vs $1.1 \%$, $P<0.001)$ and edema $(0.3 \%$ vs $0.1 \%, P=0.01)$. In the combination group, the primary outcome was seen with $16.3 \%$ showing no significant difference between the two drugs. Thus, telmisartan was equally effective as ramipril in treating patients with cardiovascular disease or high-risk diabetes. Therefore, the ONTARGET study concluded that ARBs were not inferior to ACE inhibitors with regard to benefit beyond blood pressure control.

A study called Telmisartan Randomised AssessmeNt Study in ACE iNtolerant subjects with cardiovascular Disease (TRANSCEND) was also performed simultaneously in order to evaluate whether telmisartan would be effective for patients with cardiovascular disease or diabetes with end-organ damage who are intolerant to ACE inhibitors. ${ }^{28}$ In this study, after a 3-week run-in period, 5926 patients were randomly assigned to the telmisartan $(\mathrm{n}=2954)$ and placebo groups $(\mathrm{n}=$ 2972). The primary outcome, the composite of cardiovascular death, myocardial infarction, stroke, or hospitalization for heart failure, occurred in $15.7 \%$ of patients in the telmisartan group and $17.0 \%$ of the patients in the placebo group, demonstrating no significant difference between these groups $(P=0.216)$. The secondary outcome, the composite of cardiovascular death, myocardial infarction, or stroke, occurred in $13 \%$ of patients in the telmisartan group and $14.8 \%$ of patients in the placebo group $(P=0.048$ unadjusted; $P=$ 0.068 after adjustment for multiplicity of comparisons and overlap with primary outcome), indicating a reduction in relative risk by $13 \%$.

As mentioned previously, former studies including LIFE, ${ }^{29}$ VALUE, ${ }^{30}$ and CHARM-Alternative ${ }^{31}$ demonstrated that ARBs increased the rates of myocardial infarction compared with their opponent drugs. Although no significant difference was observed between the losartan and atenolol groups in the LIFE study, (9.2\% vs 8.7\%), higher rates of myocardial infarction were observed in those who received the ARB treatment (1.07 [0.88-1.31], $P=0.491)$. In the VALUE trial, of the patients assigned to the valsartan base regimen, 369 patients $(4.8 \%)$ suffered from myocardial infarction. On the other hand, 313 patients (4.1\%) suffered from myocardial infarction in the amlodipine base regimen (Hazard Ratio 1.19 [1.02-1.38], $P=0.02$ ). The CHARM-Alternative trial also demonstrated that an ARB had a higher incidence of myocardial infarction. The total number of patients who suffered from myocardial infarction was 75 in the candesartan group and 48 in the placebo group (1.52 [1.06-2.18], $P=0.025)$. The results of these studies raised a concern that the administration of ARBs possibly increases the rate or occurrence of myocardial infarction. The myocardial infarction rate achieved by the TRANSCEND study put an end to this concern. The telmisartan group had a lower myocardial infarction rate than that in the placebo group, despite no significant statistical difference (3.9\% vs 5.0\%, $P=0.059)$. TRANSCEND is the only study that demonstrated the effectiveness of telmisartan in reducing the incidences of myocardial infarction. This study therefore helped to identify the class effect among the available ARBs.

\section{Characteristics of telmisartan/ HCTZ tablets}

Despite the evidence described previously in this paper, many patients with hypertension fail to achieve their BP goals in contemporary clinical practice, thereby motivating pharmaceutical manufacturers to develop a combination tablet. The combination of telmisartan at $40 \mathrm{mg}$ and hydrochlorothiazide (HCTZ) at $12.5 \mathrm{mg}$ (telmisartan $40 \mathrm{mg} / \mathrm{HCTZ} 12.5 \mathrm{mg}$ combination tablets) or telmisartan $80 \mathrm{mg}$ and HCTZ $12.5 \mathrm{mg}$ (telmisartan $80 \mathrm{mg} / \mathrm{HCTZ} 12.5 \mathrm{mg}$ combination tablets) was introduced recently and is now available on the international market, including Japan.

Table 2 Summary of clinical trials investigating efficacy of telmisartan/HCTZ tablets

\begin{tabular}{|c|c|c|}
\hline Names of the clinical trial or the authors & Study subjects & Main results \\
\hline Higaki ${ }^{32}$ & Hypertensive patients & $\begin{array}{l}\text { Greater reduction of BP } \\
\text { than telmisartan alone }\end{array}$ \\
\hline Lacourcière et $a^{33}$ & Hypertensive patients & $\begin{array}{l}\text { Greater reduction of BP } \\
\text { than telmisartan alone }\end{array}$ \\
\hline Neutel et $\mathrm{al}^{38}$ & Hypertensive patients & $\begin{array}{l}\text { Greater reduction of BP } \\
\text { than losartan/HCTZ tablets }\end{array}$ \\
\hline SMOOTH study ${ }^{39}$ & $\begin{array}{l}\text { Overweight/obese } \\
\text { hypertensive patients }\end{array}$ & $\begin{array}{l}\text { Greater reduction of BP } \\
\text { than valsartan/HCTZ tablets }\end{array}$ \\
\hline
\end{tabular}

Abbreviation: BP, blood pressure; HCTZ, hydrochlorothiazide. 
As mentioned previously, telmisartan is expected to yield a strong and stable antihypertensive effect over a prolonged period of time due to strong binding to the AT1 receptor and long action. HCTZ is a type of thiazide diuretic, but its diuretic effect is weaker than the loop diuretic agent. Despite its gradual onset of antihypertensive effect, HCTZ has strong and promising effects, especially for patients with salt-sensitive hypertension.

\section{Antihypertensive effects of telmisartan/HCTZ combination tablets}

The Japanese phase III clinical trial of the telmisartan $40 \mathrm{mg} / \mathrm{HCTZ} 12.5 \mathrm{mg}$ combination tablet was conducted on 213 patients with essential hypertension who failed to achieve their BP goals (diastolic BP $<90 \mathrm{mmHg}$ ) with $40 \mathrm{mg}$ telmisartan. These patients were randomly assigned to the study (telmisartan $40 \mathrm{mg} / \mathrm{HCTZ} 12.5 \mathrm{mg}$ combination tablet) and control groups (telmisartan $40 \mathrm{mg}$ ). Patients with poor compliance were excluded from the study. The primary endpoint was trough sitting BP after 8 weeks from the onset of the study. At the end of the study period, systolic and diastolic BP were decreased by $23.3 \mathrm{mmHg}$ and $14.1 \mathrm{mmHg}$ in the study group 2 weeks following the wash-out. After randomization, the BP-lowering effect was significantly greater in the study group than in the control group (systolic BP $-14.0 \mathrm{mmHg}$ vs $-8.4 \mathrm{mmHg}, P=0.001$; diastolic BP $-9.7 \mathrm{mmHg}$ vs $-5.0 \mathrm{mmHg}, P<0.0001) .{ }^{32}$ Given the fact that the subjects in this study were poor responders who failed to achieve their BP goals with telmisartan at $40 \mathrm{mg}$, reduction in systolic BP by $23.3 \mathrm{mmHg}$ was significant within the current hypertension management (Table 2).

Furthermore, the safety and efficacy of the telmisartan $80 \mathrm{mg} / \mathrm{HCTZ} 12.5 \mathrm{mg}$ combination tablet were evaluated by Lacourcière et al. ${ }^{33}$ In this study, the antihypertensive effects of a fixed-dose combination of telmisartan $80 \mathrm{mg} / \mathrm{HCTZ} 12.5 \mathrm{mg}$, and telmisartan $80 \mathrm{mg}$ monotherapy were compared with patients who had a history of mild to moderate essential hypertension and inadequate BP control following 8 weeks of telmisartan monotherapy. At the end of this period, 491 patients whose diastolic BP was $\geq 90 \mathrm{mmHg}$ were double-blind randomized to once-daily administration of telmisartan $80 \mathrm{mg} / \mathrm{HCTZ} 12.5 \mathrm{mg}(\mathrm{n}=$ 246) or telmisartan $80 \mathrm{mg}(\mathrm{n}=245)$. Following 4 and 8 weeks of double-blind therapy, trough clinic BP was evaluated. At the end of the double-blind treatment, it was found that patients who underwent telmisartan $80 \mathrm{mg} / \mathrm{HCTZ} 12.5 \mathrm{mg}$ therapy experienced a further significant decrease in clinic systolic/diastolic BP $(-5.7 \mathrm{mmHg})$ compared with those who underwent telmisartan $80 \mathrm{mg}$ monotherapy $(-3.1 \mathrm{mmHg})$ $(P<0.01)$. In addition, the number of patients with normalized BP was significantly higher in the telmisartan $80 \mathrm{mg} / \mathrm{HCTZ} 12.5 \mathrm{mg}$ group than in the telmisartan $80 \mathrm{mg}$ group $(41.5 \%$ vs $26.1 \% ; P<0.05)$. The results of this study demonstrated that a fixed-dose combination of telmisartan $80 \mathrm{mg} / \mathrm{HCTZ} 12.5 \mathrm{mg}$ yields greater reduction in BP in nonresponders than for those who continue telmisartan monotherapy. Although the difference in the reduction of BP was small, it was still considered to be big enough to be economically effective, because decreases in systolic BP as small as $2 \mathrm{mmHg}$ have a great impact on reducing mortality from cardiovascular disease. ${ }^{34}$

In addition, the dose determination study comparing telmisartan $80 \mathrm{mg} / \mathrm{HCTZ} 12.5 \mathrm{mg}$ vs telmisartan $40 \mathrm{mg} / \mathrm{HCTZ}$ $12.5 \mathrm{mg}$ demonstrated that telmisartan $80 \mathrm{mg} / \mathrm{HCTZ} 12.5 \mathrm{mg}$ was significantly more effective than telmisartan $40 \mathrm{mg} / \mathrm{HCTZ}$ $12.5 \mathrm{mg}$ in reducing mean supine diastolic BP and systolic BP $(P<0.05$ for both $){ }^{35}$

In the Japanese dose determination study (phase II), responders were defined as patients who achieved their systolic BP goals $<140 \mathrm{mmHg}$, or those whose systolic BP was less than $10 \mathrm{mmHg}$. Based on this definition, $87.5 \%$ of the patients in the telmisartan $40 \mathrm{mg} / \mathrm{HCTZ} 12.5 \mathrm{mg}$ group and $93.7 \%$ of the patients in the telmisartan $80 \mathrm{mg} / \mathrm{HCTZ}$ $12.5 \mathrm{mg}$ group achieved their treatment goal. ${ }^{36}$ Furthermore, the Japanese prolonged-administration study for 184 essential hypertensive patients who failed to achieve their BP goals with telmisartan $40 \mathrm{mg}$ demonstrated a favorable BP control with both telmisartan $40 \mathrm{mg} / \mathrm{HCTZ} 12.5 \mathrm{mg}$ tablets and telmisartan $80 \mathrm{mg} / \mathrm{HCTZ} 12.5 \mathrm{mg}$ tablets, with BP-lowering effects maintained for long-term periods. ${ }^{37}$

\section{Comparison with other combination tablets}

To evaluate the effectiveness of fixed-dose combinations of ARBs with HCTZ, a multicenter, randomized, prospective, open-label, blinded-endpoint clinical study involving 805 patients with mild-to-moderate hypertension was conducted ${ }^{38}$ The patients were randomly divided into 3 groups: telmisartan $40 \mathrm{mg} / \mathrm{HCTZ} 12.5 \mathrm{mg}$, losartan $50 \mathrm{mg}$ plus HCTZ, or telmisartan $80 \mathrm{mg} / \mathrm{HCTZ} 12.5 \mathrm{mg}$. The primary endpoint of the mean reductions in the last 6 hours mean diastolic BP for the telmisartan $40 \mathrm{mg} / \mathrm{HCTZ} 12.5 \mathrm{mg}$ and telmisartan $80 \mathrm{mg} / \mathrm{HCTZ} 12.5 \mathrm{mg}$ group were significantly higher: $-2.0 \mathrm{mmHg}(P=0.0031)$ and $-2.8 \mathrm{mmHg}$ 
$(P=0.0003)$, respectively. The study demonstrated that during the last 6 hours of the 24-hour dosing interval, telmisartan $40 \mathrm{mg} / \mathrm{HCTZ} 12.5 \mathrm{mg}$ produced a significantly reduced $\mathrm{BP}$ than losartan $50 \mathrm{mg} / \mathrm{HCTZ} 12.5 \mathrm{mg}$, which corresponds to the high-risk early-morning hours. (This study also showed further BP reduction by the administration of telmisartan $80 \mathrm{mg} / \mathrm{HCTZ} 12.5 \mathrm{mg}$ ). Therefore, telmisartan $40 \mathrm{mg} / \mathrm{HCTZ} 12.5 \mathrm{mg}$ is considered to inhibit the early morning BP elevation, and is thereby expected to prevent the onset of cardiovascular events.

The San Marino Observational Outlooking Trial on Hypertension study (SMOOTH), a prospective, randomized, open-label, blinded-endpoint, multicenter trial, compared the BP-lowering effect between telmisartan $80 \mathrm{mg} / \mathrm{HCTZ}$ $12.5 \mathrm{mg}$ and valsartan $160 \mathrm{mg} / \mathrm{HCTZ} 12.5 \mathrm{mg}$ for 840 overweight/obese hypertensive patients. ${ }^{39}$ After 10 weeks, the telmisartan $80 \mathrm{mg} / \mathrm{HCTZ} 12.5 \mathrm{mg}$ group showed significantly greater reductions in BP than the valsartan $160 \mathrm{mg} / \mathrm{HCTZ}$ $12.5 \mathrm{mg}$ group in the last 6-hour mean ambulatory BP, and differences in favor of telmisartan/HCTZ: systolic BP $3.0 \mathrm{mmHg}, P=0.0002$; diastolic BP $1.6 \mathrm{mmHg}, P=0.0006$ ) in the morning as well as during daytime and night-time periods $(P<0.003)$. Thus, the combination of telmisartan $80 \mathrm{mg}$ plus HCTZ $12.5 \mathrm{mg}$ could be a more preferable treatment alternative than valsartan $160 \mathrm{mg}$ plus HCTZ $12.5 \mathrm{mg}$, especially for overweight/obese patients with hypertension.

\section{Safety of telmisartan/HCTZ combination tablets}

The adverse event rate with the telmisartan $40 \mathrm{mg} / \mathrm{HCTZ}$ $12.5 \mathrm{mg}$ combination tablet in the Japanese study was $11.2 \%$ $(47 / 421)^{32}$ : postural vertigo (12), dizziness (10), hyperuricemia (7), light-sensitive response (4), hypotension (3), hepatic dysfunction (3), and pollakiuria (2). In the Japanese phase III study, the patients who received telmisartan $40 \mathrm{mg} / \mathrm{HCTZ}$ $12.5 \mathrm{mg}$ combination tablet for 8 weeks showed no significant changes in serum $\mathrm{K}^{+}$, serum total cholesterol, and blood glucose levels. Although elevation in the serum uric acid level was observed in the early phase, it declined gradually. ${ }^{36}$ In this situation, long-term use of telmisartan/HCTZ combination tablet least affects the metabolic pathway and does not clinically induce adverse effects.

\section{Conclusions}

Reduction in the number of drugs enhances the drug compliance rate. For those who poorly responded and failed to achieve their BP goals with a single antihypertensive drug, the combination of ARB/HCTZ possibly offers additional benefits. The telmisartan/HCTZ combination tablet was demonstrated to have a strong and long-acting effect. Therefore, for the management of hypertension as recommended by the revised version of JSH 2009, using the telmisartan/HCTZ combination tablet has enormous promise in contemporary medical treatment.

\section{Disclosure}

The authors report no conflicts of interest in this work.

\section{References}

1. Ogihara T, Kikuchi K, Matsuoka H, et al. Japanese Society of Hypertension Committee. The Japanese Society of Hypertension Guidelines for the Management of Hypertension (JSH 2009). Hypertens Res. 2009;32:4-107.

2. Obara T, Ohkubo T, Funabashi J, et al. Isolated uncontrolled hypertension at home and in the office among treated hypertensive patients from the J-HOME study. J Hypertens. 2005;23:1653-1660.

3. Itoh S. Synergic effect mechanisms on $\mathrm{ARB} /$ diuretic combination tablets. J Blood Press. 2006;13:1304-1307.

4. Siragy HM, Bedigian M. Mechanism of action of angiotensin-receptor blocking agent. Curr Hypertens Rep. 1999;1:289-295.

5. Siragy HM. AT (1) and AT (2) receptors in the kidney: role in disease and treatment. Am J Kidney Dis. 2000;36(3 Suppl 1):S4-S9.

6. Weir MR, Dzau VJ. The renin-angiotensin-aldosterone system: a specific target for hypertension management. Am J Hypertens. 1999;12:S205-S213.

7. Schiffrin EL. Vascular and cardiac benefits of angiotensin receptor blockers. Am J Med. 2002;113:409-418.

8. Schmieder RE. Mechanisms for the clinical benefits of angiotensin II receptor blockers. Am J Hypertens. 2005;18:720-730.

9. Morimoto S, Yano Y, Maki K, Sawada K. Renal and vascular protective effects of telmisartan in patients with essential hypertension Hypertens Res. 2006;29:567-572.

10. Wienen W, Entzeroth M, van Meel JC, et al. A review on telmisartan: a novel, long-acting angiotensin II-receptor antagonist. Cardiovasc Drug Rev. 2000;18:127-156.

11. Sharpe M, Jarvis B, Goa KL. Telmisartan: a review of its use in hypertension. Drugs. 2001;61:1501-1529.

12. Lacourcière Y, Krzesinski JM, White WB, Davidai G, Schumacher H. Sustained antihypertensive activity of telmisartan compared with valsartan. Blood Press Monit. 2004;9:203-210.

13. Benson SC, Pershadsingh HA, Ho CI, et al. Identification of telmisartan as a unique angiotensin II receptor antagonist with selective PPARgamma-modulating activity. Hypertension. 2004;3: 993-1002.

14. Schupp M, Janke J, Clasen R, et al. Angiotensin type I receptor blockers induce peroxisome proliferators-activated receptor-gamma activity. Circulation. 2004;109:2054-2057.

15. Janke J, Schupp M, Engeli S, et al. Angiotensin type 1 receptor antagonists induce human in vitro adipogenesis through peroxisome proliferatorsactivated receptor- $\gamma$ activation. J Hypertens. 2006;24:1809-1816.

16. Erbe DV, Gartrell K, Zhang YL, et al. Molecular activation of PPAR$\gamma$ by angiotensin II type 1-receptor antagonists. Vasc Pharmaco. 2006;45:154-162.

17. Perhadsingh HA. Peroxisome proliferator-activated receptor- $\gamma$ therapeutic target of diseases beyond diabetes: quo vadis? Expert Opin Invest Drugs. 2004;13:215-228.

18. Savage DB, Tan GD, Acerini CL, et al. Human metabolic syndrome resulting from dominant-negative mutations in the nuclear receptor peroxisome proliferator-activated receptor- $\gamma$. Diabetes. 2003;52: 910-917. 
19. Schupp M, Clemenz M, Gineste R, et al. Molecular characterization of new selective peroxisome proliferator-activated receptor gamma modulators with angiotensin receptor blocking activity. Diabetes. 2005;54:3442-3452.

20. Miura Y, Yamamoto N, Tsunekawa S, et al. Replacement of valsartan and candesartan by telmisartan in hypertensive patients with type 2 diabetes. Diabetes Care. 2005;28:757-758.

21. Yamauchi T, Kamon J, Waki Y, et al. The fat-derived hormone adiponectin reverses insulin resistance associated with both lipotrophy and obesity. Nat Med. 7:941-946.

22. Ross R. Atherosclerosis: An inflammatory disease. $N$ Engl J Med. 1999;340:115-126.

23. The SOLVD Investigators. Effect of enalapril on survival in patients with reduced left ventricular ejection fractions and congestive heart failure. N Engl J Med. 1991;325:293-302.

24. Pfeffer MA, Braunwald E, Moyé LA, et al. Effect of captopril on mortality and morbidity in patients with left ventricular dysfunction after myocardial infarction: Results of the survival and ventricular enlargement trial. N Engl J Med. 1992;327:669-677.

25. Heart Outcomes Prevention Evaluation Study Investigators. Effects of ramipril on cardiovascular and microvascular outcomes in people with diabetes mellitus: Results of the HOPE study and MICRO-HOPE substudy. Lancet. 2000;355:253-259. [Erratum, Lancet. 2000;356:860.]

26. Blood Pressure Lowering Treatment Trialists' Collaboration. Blood pressure-dependent and independent effects of agents that inhibit the renin-angiotensin system. J Hypertens. 2007;25:951-958.

27. The ONTARGET Investigators. Telmisartan, ramipril, or both in patients at high risk for vascular events. $N$ Engl J Med. 2008;358: 1547-1559.

28. The Telmisartan Randomised AssessmeNt Study in ACE iNtolerant subjects with cardiovascular Disease (TRANSCEND) Investigators. Effects of the angiotensin-receptor blocker telmisartan on cardiovascular events in high-risk patients intolerant to angiotensin-converting enzyme inhibitors: a randomised controlled trial. Lancet. 2009;372:1174-1183.

29. Lindholm LH, Ibsen H, Dahlof B, et al. Cardiovascular morbidity and mortality in patients with diabetes in the Losartan Intervention For Endpoint reduction in hypertension study (LIFE): A randomised trial against atenolol. Lancet. 2002;359:995-1003.
30. Julius S, Kjeldsen SE, Weber M, et al. Outcomes in hypertensive patients at high cardiovascular risk treated with regimens based on valsartan or amlodipine: The VALUE randomised trial. Lancet. 2004;363:20222031.

31. Granger CB, McMurray JV, Yusuf S, et al. Effects of candesartan in patients with chronic heart failure and reduced left-ventricular systolic function intolerant to angiotensin-converting-enzyme inhibitors: The CHARM-Alternative trial. Lancet. 2003;362:772-776.

32. Higaki J. The examination of telmisartan $40 \mathrm{mg}$ /hydrochlorothiazide for patients with essential hypertension. J New Remedies and Clinic. 2008;57:308-325.

33. Lacourcière Y, Tytus R, O'Keefe D, Lenis J, Orchard R, Martin K Efficacy and tolerability of a fixed-dose combination of telmisartan plus hydrochlorothiazide in patients uncontrolled with telmisartan monotherapy. J Hum Hypertens. 2001;15:763-770.

34. Stamler J, Rose G, Stamler R, Elliott P, Dyer A, Marmot M. INTERSALT study findings. Public health and medical care implication. Hypertension. 1989;14:570-577.

35. McGill JB, Reilly PA. Telmisartan plus hydrochlorothiazide versus telmisartan or hydrochlorothiazide monotherapy in patients with mild to moderate hypertension: A multicenter, randomized, double-blind, placebo-controlled, parallel-group trial. Clin Ther. 2001;23:833-850.

36. Internal document for Nippon Boehringer Ingelheim (data submitted to the Japanese Ministry of Health and Labor for the approval of telmisartan/HCTZ combination tablets)

37. Higaki J. The examination of long-term usage of telmisartan $40 \mathrm{mg}$ / hydrochlorothiazide tablet and telmisartan $80 \mathrm{mg} /$ hydrochlorothiazide tablet for patients with essential hypertension. $J$ New Remedies and Clinic. 2009;58:346-361.

38. Neutel JM, Littlejohn TW, Chrysant SG, Singh A; Telmisartan Study Group. Telmisartan/hydrochlorothiazide in comparison with losartan hydrochlorothiazide in managing patients with mild-to-moderate hypertension. Hypertens Res. 2005;28:555-563.

39. Sharma AM, Davidson J, Koval S, Lacourcière Y. Telmisartan/ hydrochlorothiazide versus valsartan/hydrochlorothiazide in obese hypertensive patients with type 2 diabetes: The SMOOTH study. Cardiovasc Diabetol. 2007;6:28.
Integrated Blood Pressure Control

\section{Publish your work in this journal}

Integrated Blood Pressure Control is an international, peer-reviewed open-access journal focusing on the integrated approach to managing hypertension and risk reduction. Treating the patient and comorbidities together with diet and lifestyle modification and optimizing healthcare resources through a multidisciplinary team approach constitute key

\section{Dovepress}

features of the journal. This journal is indexed on American Chemical Society's Chemical Abstracts Service (CAS). The manuscript management system is completely online and includes a very quick and fair peerreview system, which is all easy to use. Visit http://www.dovepress.com/ testimonials.php to read real quotes from published authors. 